\title{
NGOs, Intellectual Property Rights and Multilateral Institutions
}

\author{
Duncan Matthews
}

Report of the IP-NGOs research project

Published December 2006

Queen Mary Intellectual Property Resea rch Institute

Centre for Commercial Law Studies

Queen Mary, University of London

J ohn Vane Science Centre

Charterhouse Square

London EC1M 6BQ

United Kingdom

Tel: +44 (0)20 78823445

Fax: +44 (0)20 78823446

Email: d.n.matthews@gmul.ac.uk

IP-NG Os website: www.ipngos.org

Funded by the Economic and Social Research Counc il (ESRC) 


\section{CONTENTS}

\section{Executive summary}

1. Introduction.

2. Findings: International NGOs

3. Findings: Southern NGOs, social movements, indigenous groups and local communities....20

4. Findings: Relations between public action NGOs and industry.

5. Findings: Arrangements for NGO engagement with multilateral institutions

6. Findings: Planning responses to new and emerging issues.

7. Recommendations.

Appendix: Interviews conducted for the IP-NGOs project .... .35 


\section{EXECUTIVE SUMMARY}

This report sets out the key findings of an independent academic research project investigating the significance of non-governmental organisations for intellectual property rights and multilateral institutions (the IP-NGOs project). Based on over sixty face-to-face interviews with representatives of key NGOs, developing country delegations and the secretariats of multilateral institutions, the IP-NGOs project has analysed patterns in recent activity by NGOs in relation to intellectual property issues in the World Trade Organisation (WTO); the World Intellectual Property Organisation (WIPO); the World Health Organisation (WHO); the Convention on Biological Diversity Conference of the Parties (CBD-COP); and the Food and Agriculture Organisation (FAO) of the United Nations.

Section 1 of the report explains how the project originated as a response to the UK Commission on Intellectual Property Rights. Section 2 then looks at how and why international NGOs play an important role in supporting the work of delegates to multilateral institutions. It also suggests further activities that international NGOs could undertake in the future. Section 3 describes how NGOs, social movements, indigenous groups and local communities in developing countries have played a key role in raising awareness of the implications of intellectual property policy for development policy. It identifies the limits to what groups in the South have been able to achieve and suggests how they could make more effective inputs in the future. Section 4 looks at relations between public action NGOs and industry, highlighting barriers to dialogue and instances where good relations have been established. Section 5 assesses current arrangements for NGO engagement with multilateral institutions and suggests how these arrangements could be enhanced in the future. Section 6 examines how NGOs are planning responses to new and emerging issues. It also explains the limits to what NGOs can hope to achieve. Section 7 concludes the report by setting out six recommendations for international NGOs, for multilateral institutions and for the donors of funds that support the work of NGOs. 


\section{INTRODUCTION}

\subsection{The IP-NGOs project}

This report sets out the key findings of an independent academic research project investigating the significance of non-governmental organisations for intellectual property rights and multilateral institutions (the IP-NGOs project). The report is intended to summarise findings and recommendations of the IP-NGOs project for users in the policy-making community. Following publication of this report, further publications in the form of academic journal articles and a book will report on the project in greater detail.

The IP-NGOs project aims to identify patterns in recent activity by NGOs in relation to intellectual property policy-making and norm-setting in the World Trade Organisation (WTO); the World Intellectual Property Organisation (WIPO); the World Health Organisation (WHO); the Convention on Biological Diversity Conference of the Parties (CBD-COP); and the Food and Agriculture Organisation (FAO) of the United Nations.

The research was funded with public money administered by the Economic and Social Research Council (ESRC). The ESRC receives most of its funding through the UK Government's Office of Science and Innovation. The ESRC generously funded the IP-NGOs project as part of the larger ESRC Non-Governmental Public Action (NGPA) programme of research. The NGPA programme focuses on non-governmental action by and behalf of disadvantaged people, the impact of nongovernmental public action in reducing poverty and exclusion, and on social transformation, from an international comparative and multi-disciplinary perspective. The IP-NGOs project began in October 2005 and ended in December 2006. Duncan Matthews was the principal investigator for the IP-NGOs project. Viviana Munoz Tellez was the full-time Research Assistant.

The project website is available at: www.ipngos.org. Included in the resources available on the website is an 'NGOs in Action' page, which provides non-technical summaries of how NGOs have engaged with intellectual property issues in the past, and an 'NGO Profiles' page, which provides a lengthy but by no means exhaustive list of NGOs that are active in relation to intellectual property issues, with brief descriptions and full contact details of each organisation. The website is intended as an information and networking resource for NGOs and government officials from developing countries.

\subsection{Rationale for the IP-NGOs project}

In May 2001, as part of the UK Government's commitment in the second White Paper on International Development, "Eliminating World Poverty: Making Globalisation Work for the Poor" (2000), the Secretary of State for International Development established the Commission on Intellectual Property Rights. The Commission undertook the task of considering whether and how intellectual property rights could play a role in helping to meet targets identified in the United Nations' The Millennium Development Goals in relation to the reduction of world poverty and hunger, the improvement of health and education, and ensuring environmental sustainability.

When the Commission on Intellectual Property Rights published its report Integrating Intellectual Property Rights and Development Policy in 2002, a key finding was the recent extent and influence of NGO activity in relation to intellectual property rights. Specifically, the Commission reported that NGOs have made, and can continue to make in the future, a positive contribution to the promotion of the concerns of developing countries about the impact of intellectual property rights. The IP-NGOs project takes this statement as its starting point. 
'We have been struck by the recent extent and influence of NGOs' activity in IP. We believe that NGOs have made, and can continue to make in the future, a positive contribution to the promotion of the concerns of developing countries."

Source: Commission on Intellectual Property Rights (2002) "Integrating Intellectual Property Rights and Development Policy", page 165.

Furthermore, because the Commission on Intellectual Property Rights went on to suggest that the role of NGOs has been particularly notable in relation to (i) public health and access to essential medicines; and (ii) agriculture, genetic resources and traditional knowledge, the IP-NGOs project focused on these two sets of issues.

"Campaigns to raise awareness by development and health NGOs were important factors in supporting developing countries in their negotiations of the Ministerial Declaration at Doha. In the fields of agriculture, genetic resources and traditional knowledge, certain NGO groups play an important role in highlighting and analysing issues of concern to developing countries."

Source: Commission on Intellectual Property Rights (2002) "Integrating Intellectual Property Rights and Development Policy", page 165.

\subsection{Aims of the IP-NGOs project}

The IP-NGOs project had 5 aims:

1. To gather evidence on the extent of recent NGO activity in relation to intellectual property issues and multilateral institutions, ascertaining what interests NGOs represent, what campaigning activities and methods are used and what successes NGOs have had in the context of discussions and negotiations on intellectual property issues that have taken place in multilateral institutions.

2. To identify the extent and significance of relations between 'Northern' and 'Southern' NGOs in relation to intellectual property issues.

3. To investigate the significance of relations between NGOs and developing countries in the context of intellectual property issues and multilateral institutions.

4. To examine the extent to which linkages have emerged between NGOs and industry.

5. To assess the appropriateness of current institutional arrangements for NGO participation at multilateral institutions in relation to intellectual property issues and to consider whether new mechanisms are required to enhance the engagement of NGOs with multilateral institutions.

\section{$1.4 \quad$ Research method}

In order to fulfil these aims, the research team of Matthews and Munoz Tellez undertook over sixty interviews with representatives of NGOs, developing country governments and multilateral institutions, augmented by further interviews with representatives from academia, industry associations and rights holder groups. The interviews, which commenced in late November 2005 and ended in early June 2006, were conducted face-to-face in Switzerland, South Africa, Brazil, India and the UK. A small number of additional interviews were conducted by telephone and some written responses were also received.

A list of the individuals interviewed and their affiliations is set out at the end of this report. Interviews were conducted using a structured questionnaire. However the views expressed in this report do not necessary reflect the opinion of any individuals or organisations that have assisted with the IP-NGOs project.

Interviewees were asked to respond on the understanding that their comments would be reported on a non-attributable basis to elicit as full and frank a response as possible. The research findings 
presented in this report therefore reflect general trends, common themes and characterisations rather than the views of particular individuals or organisations.

In addition to the interviews undertaken during the fieldwork for the IP-NGOs project, initial findings were presented at a side event held the WIPO Provisional Committee on the Development Agenda (PCDA) in Geneva on 28 June 2006. The IP-NGOs side event at the PCDA, which was attended by 45 delegates and accredited NGOs, was designed as a mechanism to obtain feedback and has assisted with the writing of this report.

\subsection{Intended research impact}

The IP-NGOs project is intended to inform the debate about the extent and influence of nongovernmental public action and to recommend how NGOs can best play a constructive role in shaping future intellectual property policy initiatives.

For participating NGOs, the project is intended to provide a framework within which strategic decisions can be taken in the future. This involves identifying current practice in NGOs' methods and activities and evaluating what degree of input has been made thus far in terms of intellectual property issues discussed in the context of multilateral institutions.

In particular, identifying current practice is intended to be of value to 'Southern' NGOs which, while fast developing a profile in relation to the impact of intellectual property rights on public health, farmers' rights, biodiversity and the rights of indigenous peoples, are often perceived as lacking the experience of their 'Northern' NGO counterparts.

For representatives of developing country governments, the project is intended provide an indication of the significance of inputs from NGOs, identifying instances where these NGOs have worked previously with developing countries and ascertaining whether these relationships have been significant in relation to intellectual property issues during negotiations at the multilateral institutional level.

For policy-makers, the project is intended as an assessment of current multilateral institutional arrangements for engagement with NGOs. The project has also sought to ascertain whether enhanced or revised institutional arrangements could be put in place to develop further the engagement of NGOs with multilateral institutions on intellectual property issues.

\subsection{Methodological issues}

\subsubsection{Terminology}

NGOs are not a homogeneous group. An important distinction must be made at the outset between public action NGOs, industry associations, rights holder groups, professional associations made up of intellectual property lawyers and other related professions, and the academic community. All are types of non-governmental organisations.

There is no uniform definition for NGO accreditation to multilateral institutions. Recently, for instance, the definition of accredited NGOs has been subject to discussion at meetings of the WIPO Provisional Committee on the Development Agenda (PCDA) and at the Eight Meeting of the Convention on Biodiversity Conference of the Parties (CBD-COP 8). At present, in the WTO and WIPO context, the definition of NGO extends to both public action and industry NGOs, while the CBD-COP has different categories of accreditation for NGOs, industry and indigenous peoples.

The IP-NGOs project, however, is concerned only with the first category: public action NGOs. The term NGOs is used in this report to denote only this category. The reason for this restricted use of the term can be found in the ESRC NGPA Programme, under which the IP-NGOs project has been funded. The terms of reference for the NGPA Programme refer explicitly to research on non-governmental public action by and behalf of disadvantaged people and on studying the impact of non-governmental public action in reducing poverty and exclusion. In this respect, 
although a small number of representatives of industry associations, rights holder groups and the academic community were interviewed for this project, this was primarily in order to ascertain how public action NGOs were perceived and how industry associations, rights holder groups and academics interact with public action NGOs in the context of multilateral institutions and intellectual property rights.

Complexities also arise in terms of the traditional distinction between 'Northern' and 'Southern' NGOs. Broadly speaking, Northern NGOs are considered to be those that are formally established in developed countries, with their head offices and primary sources of funding found there. However, the distinction is not clear-cut. ActionAid, for example, is traditionally considered to be a Northern NGO but now has its head office located in Johannesburg, South Africa. ActionAid cannot, however, be considered a Southern NGO, particularly because of the global reach of its activities and it's funding, much of which is derived from donors in the United Kingdom. Indeed, there are also a number of large NGOs, such as ActionAid, Oxfam and Médecins Sans Frontières (MSF), which have branches and associate organisations or individuals in many countries, including developing countries and that have long records of action in the developing world, which again blurs the distinction between the North and the South.

There are also NGOs from the South that work at an international level, such as Third World Network (TWN), as well as NGOs that work at a national level in the South, such as TAC in South Africa or IDCID in Brazil, that have received significant funding from donors in the North, such as large charitable foundations in the United States, so the question arises as to whether these organisations can properly be described as Southern NGOs.

In many respects, therefore, although the relationship between Northern and Southern NGOs will be investigated further in this report, a key distinction for the IP-NGOs project is also the extent to which NGOs are either international in focus, with a profile when intellectual property issues are discussed and negotiated in multilateral forums, or national in focus and operating exclusively in the South. While the primary focus of the IP-NGOs project is on international NGOs, the project is also looking at relations between international NGOs and NGOs that are active at the national, regional or sub-national level in the South, and the ways that NGOs in the South address intellectual property issues in that context.

In addition to the role played by international and Southern NGOs, societal involvement is also crucial in terms of efforts to shape and change intellectual property rules. Accordingly, the IPNGOs project has looked specifically at three developing countries where NGOs, social movements, indigenous groups and local communities have a strong tradition of engagement with intellectual property issues: South Africa; Brazil and India. Examples of societal involvement from each of these countries will be used to illustrate this report.

There are also other organisations that are not NGOs that have emerged as important actors when intellectual property issues discussed and negotiated in multilateral institutions. IP-Watch, for example undertakes journalistic work, while South Centre is an intergovernmental organisation that interfaces with both developing countries and NGOs in Geneva. Representatives of both these organisations were interviewed for the project.

\subsubsection{Selection of case studies}

The selection of the case studies for the IP-NGOs project was informed by the UK Commission on Intellectual Property Rights report, which suggested that the role of NGOs had been particularly notable in relation to (i) public health and access to medicines and (ii) agriculture, genetic resources and traditional knowledge. Brief summaries of findings relating to the two case studies are contained in the appendices of this report. Further outputs of the project, in terms of journal articles and a book, will report findings from the case studies in greater detail.

Given the cross-cutting nature of the two case studies, which relate to intellectual property policymaking and norm-setting in a number of multilateral forums, the IP-NGOs project has looked at the impact that NGOs have had in relation to the WTO, WIPO, WHO, CBD-COP and the FAO. The issues involved are at times being discussed simultaneously in different multilateral forums, 
so it is extremely difficult to evaluate the specific impact that NGOs have had. This problem is exacerbated by the fact that multilateral institutions are intergovernmental in nature, so the primary focus of policy-making and norm-setting in these institutions is on Members rather than NGOs, as should properly be the case. Despite these caveats, the IP-NGOs project has been able to identify particular trends prevalent in relation to NGO engagement with multilateral institutions and the Members of those institutions. The report will set out these findings in subsequent sections.

Focusing on the two case studies also raises questions about how far the findings of the project can be considered as having wider applicability in the context of other intellectual property issues, the Access to Knowledge (A2K) movement being one notable example. It is important to acknowledge, therefore, that further work should be encouraged to consider the wider implications of findings from the IP-NGOs project for other areas of intellectual property policy. The IP-NGOs project is intended to be one contribution to a wider debate.

One further aspect of NGO engagement with intellectual property issues that came to the fore early in the IP-NGOs project and warranted an extension of the terms of reference of the research, however, was the WIPO Development Agenda. This was an issue that emerged as an issue of concern for many of the interview respondents that we spoke to. The WIPO Development Agenda emerged as a key policy issue after the terms of reference for the IP-NGOs project were put in place in August 2004 but, given the fact that the WIPO Development Agenda relates to issues covered by the two case studies, decision was taken early on to consider NGO engagement with the WIPO Development Agenda process alongside the case studies of (i) public health and access to medicines and (ii) agriculture, genetic resources and traditional knowledge. The issues covered by the two case studies are summarised in boxes 1 and 2 below.

\section{FINDINGS: INTERNATIONAL NGOS}

\subsection{International NGOs falling within the scope of the IP-NGOs project}

Box 1, below, provides examples of international NGOs falling within the scope of the IP-NGOs project.

\section{Box 1}

\section{Examples of international NGOs falling within the scope of the IP-NGOs project}

ActionAid; Center for International Environmental Law (CIEL); Consumer Project on Technology (CPTech); Action Group on Erosion, Technology and Concentration (ETC, formerly RAFI); Genetic Resources Action International (GRAIN); Health Action International (HAI); International Centre for Sustainable Trade and Development (ICTSD); Practical Action (formerly ITDG); Médecins Sans Frontières (MSF); Oxfam; Quaker United Nations Office (QUNO); Third World Network (TWN); 3D: Trade-Human Rights-Equitable Economy (3D).

\subsection{Case study summary: Public health and access to medicines}

International NGOs began to take greater interest in the implications of intellectual property for public health and access to medicines from the mid-1990s onwards. International NGOs involved have included: Consumer Project on Technology (CPTech); Health Action International (HAI); Médecins Sans Frontières (MSF); Oxfam and Third World Network (TWN). CPTech, which had become involved in access to medicines issues in the United States in 1991, began to play an international role in 1994 when it was invited to Argentina and to Brazil to talk about its work. In 1996 CPTech and MSF both participated in the HAI held a meeting in Germany on health and GATS that united the first big group on access to medicines. Then, in 1999, the MSF Access to Medicines Campaign began. An important stimulus was also provided by an article, entitled "Access to Essential Drugs in Poor Countries: A Lost Battle?" which was co-authored by Bernard Pécoult in the Journal of the American Medical Association, published in January 1999. Pécoult, 
at that time with MSF, is now Executive Director of the NGO Drugs for Neglected Diseases Initiative (DNDi). The article, which drew on the experiences of MSF doctors in the field, made the case that patents and can be a barrier to access to medicines.

During the Seattle WTO Ministerial meeting from $30^{\text {th }}$ November to $3^{\text {rd }}$ December 1999 , MSF and Oxfam called for a working group to be established on access to medicines. TWN also became involved with access to medicines issues at this point. TWN was already looking at WTO negotiating processes and was focused on articulating the concerns of grassroots communities at the international level and on bringing expertise to international policy-making, so access to medicines fitted well with the broader activities of TWN. TWN was able to initiate a dialogue with the African Group of delegations to the WTO and encouraged them to explore the prospects for coordinated action in relation to public health and access to medicines with Brazil and India. Oxfam GB launched its "Cut the Cost" campaign in March 2001, a campaign taken up by Oxfam globally. The Quakers United Nations Office (QUNO) in Geneva played a very different, but equally important, role by bringing together delegates and academic experts. Academic experts involved included Carlos Correa, Frederick Abbott, Jerome Reichman and Keith Maskus.

TRIPS and public health was an issue where there was broad unanimity of interests and shared concerns between NGOs and developing countries. It united almost all developing countries because HIVIAIDS was an issue on which there was broad sympathy and which charged strong emotions. This had the effect that developing countries welcomed NGO engagement with intellectual property rights and public health issues much more than in other policy areas.

NGOs assisted in focusing attention on the issue, mobilising the media, raising awareness and organising campaigning initiatives, and providing the technical inputs on complex legal issues. Much of the technical drafting work for the Doha Declaration on the TRIPS Agreement and Public Health was done by NGOs, who invested in involving academic experts. NGOs also coordinated their activities, working well together and forging links with developing countries in the run up to Doha Declaration on the TRIPS Agreement and Public Health. The Doha Declaration was important as a political success and raised awareness of the fact that developing countries can act legitimately to protect public health. NGOs also raised awareness among politicians and civil servants of these issues to an extent hitherto not acknowledged prior to 2001. As such, NGOs created a pressure on governments that counterbalanced the role played by industry. It opened up the debate on intellectual property rights and development policy and introduced nonintellectual property rights holding groups to the debate. However, it should be acknowledged that the Doha Declaration on the TRIPS Agreement and Public Health came about as the result of a number of factors. It was not the case that particular outcomes can be attributed solely to the input of NGOs.

After the Doha Declaration on the TRIPS Agreement and Public Health, some international NGOs that had been involved previously with public health and access to medicines issues began to prioritise other trade issues and focused less systematically on TRIPS issues, so the momentum generated by NGO engagement with the issue was not maintained. On the other hand, newer NGOs, such as 3D: Trade-Human Rights-Equitable Economy (3D) which made explicit the link between human rights, intellectual property and access to medicines, have more recently engaged with these issues.

An important lesson to be learnt from the public health and access to medicines case study is therefore that any NGO agenda, even if well coordinated, using the media and with public support, does not go forward unless there are long-term commitments on the part of NGOs to remain involved with the issue and that there are developing countries that are willing to take the issue up and articulate it during intergovernmental negotiations.

Some international NGOs and developing countries had good relationships in the context of public health and access to medicines, but these relationships were not without their tensions. The limits on what can be achieved by NGOs and developing countries is apparent in the $6^{\text {th }}$ December 2005 agreement on an amendment to the TRIPS Agreement in respect to public health needs, which developing countries agreed to despite many NGOs failing to see this as a 
workable solution. There are limitations to what can be achieved when NGOs act in support of developing countries

To summarise, on public health and access to medicines international NGOs initially worked well together and with developing countries until the issues became too technical. However, the impact of international NGOs in relation to public health and access to medicines may be difficult to replicate in the context of other issues, such as agriculture, genetic resources and traditional knowledge. Furthermore, Southern NGOs provided important inputs into the work of international NGOs. The role of Southern NGOs with intellectual property issues relating to public health and access to medicines is discussed further in section 3 of this report.

\subsection{Case study summary: Agriculture, genetic resources and traditional knowledge}

The main stimulus for international NGOs to become involved with issues relating to agriculture, genetic resources and traditional knowledge was the United Nations Conference on Environment and Development (UNCED), which took place in Rio de Janeiro, Brazil from 3 to 14 June 1992 (the Rio Earth Summit). From the Rio Earth Summit this grew the sustained involvement of international NGOs in intellectual property issues more widely, relating to Article 27.3(b) of the TRIPS Agreement, prior informed consent under the Convention of Biodiversity (CBD) and access and benefit sharing (ABS) agreements.

International NGOs that have played an important role in relation to agriculture, genetic resources and traditional knowledge include: ActionAid; the Berne Declaration; the Center for International Environmental Law (CIEL), Action Group on Erosion, Technology and Concentration (ETC, formerly RAFI); Friends of the Earth; GAIA Foundation; Genetic Resources Action International (GRAIN); Greenpeace; the International Union for the Conservation of Nature and Natural Resources (IUCN) and Practical Action (formerly ITDG). The International Centre for Trade and Sustainable Development (ICTSD) and the Quakers United Nations Office (QUNO) have also played an important role in Geneva, providing background information and support to delegates on issues relating to agriculture, genetic resources and traditional knowledge. GRAIN and ETC have made significant contributions away from Geneva, particularly in the CBD-COP and FAO contexts. There has also been a general network of groups that deal with trade and development issues more widely, including Focus on the Global South, which has made important inputs to the debate on agriculture, genetic resources and traditional knowledge. The intergovernmental organisation South Centre has also made an important contribution to the debate.

However, despite the policy space that has emerged as a result of the $6^{\text {th }}$ December 2005 agreement on a permanent amendment to TRIPS to address public health imperatives, doubts remain as to whether that progress will be replicated in other policy areas. Progress was made on access to medicines because it was seen as a global problem whereas there remains a perception that genetic resources and traditional knowledge issues are primarily issues for the South. It is also the case that the consensus on preferred outcomes and the network of international NGOs, developing countries and public opinion that emerged around issues of public health and access to medicines has been lacking in the case of genetic resources and traditional knowledge. The North-South resonance of the agriculture, genetic resources and traditional knowledge is also lacking in comparison with the profile of the public health and access to medicines debate. Unfortunately, for agriculture, genetic resources and traditional knowledge the benefit does not seem to be visible and immediate, so it is the pressure for policy outcomes is not as great as for public health and access to medicines. This has been compounded by a lack of consensus in favour of disclosure of origin proposals. Furthermore, international NGOs such as GRAIN and ETC, which are important actors in relation to the CBD-COP and WIPO Intergovernmental Committee on Intellectual Property and Genetic Resources, Traditional Knowledge and Folklore (IGC), are notable by their absence when disclosure of origin and related access and benefit sharing issues are discussed in the TRIPS Council context.

Building a consensus in favour of particular outcomes in relation to agriculture, genetic resources and traditional knowledge has been more difficult than it was in the case of public health and access to medicines. The need to make the issues identifiable remains problematic, with understanding and sympathy towards intellectual property issues relating to agriculture, genetic 
resources and traditional knowledge falling short of the levels achieved for public health and access to medicines issues.

\subsection{Analysis: the role of international NGOs multilateral forums}

\subsubsection{Enhancing the capacity of developing country delegates to negotiate}

Given the intergovernmental nature of the Member-driven multilateral institutions in which intellectual property issues are discussed and negotiated, international NGOs are not the primary actors and do not see themselves as such. International NGOs readily acknowledge that they lack the legitimacy to speak on behalf of particular constituencies and did not claim to do so. Consequently, international NGOs tend not to engage in conventional forms of advocacy and lobbying of developing country delegates to multilateral institutions. Instead, a key objective is enhancing the capacity of developing countries to negotiate.

In this respect, an important distinction can be drawn between, first, those developed (and larger developing) countries whose delegations to multilateral institutions are supported by intellectual property experts at capital level and, second, developing (and least-developed) countries that do not receive detailed advice, support, or feedback from capital level. For this second group, where delegates often cover a range of trade issues and who are unlikely to be experts on intellectual property rights, it is impossible to cover all the issues that they have within their portfolio. Delegates are nevertheless under pressure to understand and engage with intellectual property issues and need information. International NGOs meet this need by first raising awareness of the significance of intellectual property issues and by then providing advice and technical expertise to keep delegates informed.

\subsubsection{Raising awareness}

Moreover, because delegations to multilateral institutions change regularly, there is a constant need for international NGOs to renew their links with delegates and keep awareness of intellectual property issues at the fore. The constantly changing delegations have an impact on the relationships that international NGOs have with delegates in the sense that when the delegate changes there is no guarantee that the new incumbent will retain that delegation's interests in intellectual property issues because a delegate's personal interest can drive a particular delegation's engagement with intellectual property issues.

\subsubsection{Achieving coherence in multilateral forums}

Some coherence is sought by international NGOs that organise meetings and seminars to orientate new delegates. In Geneva, for many delegates, seminars organised by international NGOs are the main orientation mechanisms on intellectual property issues when they first arrive at their Missions. Delegates appreciate this support but the reality is that international NGOs are providing this support, and find delegates receptive to it, because intergovernmental organisations are not perceived by delegates to be fulfilling this need in a systematic way.

Difficulties in achieving coherence on policy positions in different multilateral forums are exacerbated by the differing relationships between the multilateral institutions themselves. This fragmentation does not help when seeking to achieve policy coherence. On disclosure of origin of genetic resources, for instance, the prospects of deliberations in different multilateral forums are made more uncertain by the fact that the CBD Secretariat has not been granted observer status in the TRIPS Council.

\subsubsection{International NGOs as facilitators}

Typically, international NGOs are facilitators. They try to increase coordination and interaction between NGOs and developing countries because they believe that dialogue is useful and worth promoting and, because developing countries' negotiating positions are often not being articulated fully at capital level and delegates are determining the positions taken without adequate support from their governments, international NGOs have sought to facilitate equitable 
outcomes to negotiations on intellectual property issues in multilateral forums. They do so by providing delegates with information and technical knowledge and, in this process, two factors are crucial: timing and trust.

\subsubsection{Timing}

Timing is important because representatives of international NGOs need to be on hand and ready to be responsive to the information needs of delegates. This means that in relation to the WTO, WIPO and WHO, for example, it is often not sufficient for representatives of NGOs to travel to Geneva for key meetings. Effective engagement on a day-to-day basis often involves a permanent presence in Geneva that allows representatives of international NGOs to establish and maintain relationships with delegates. In relation to the CBD-COP and FAO, the absence of a permanent fixed location for the delegate community creates a different dynamic, with international NGOs holding seminars and meetings before negotiations take place at periodic intergovernmental meetings and maintaining a dialogue with delegates based at capital level through regular correspondence and briefing papers.

\subsubsection{Trust}

Trust is important because delegates are more likely to respond to an individual from an international NGO with whom they have an established and positive relationship. A relationship of trust must exist before delegates feel sufficiently comfortable with international NGOs to ask for advice and technical expertise. Delegates and representatives of international NGOs interact in formal and informal settings and exchange information, share ideas and expertise. Within this process of interaction, a great deal depends on personal relationships and building trust over relatively long periods of time so, as with timing, permanent representation or at least maintaining dialogue and establishing long-term relationships is important.

\subsubsection{Cross-fertilisation of ideas}

When good relationships are formed, a two-way process of information exchange and discussion between delegates and international NGOs can occur, but the main role of NGOs in the process remains that of providing information and support. This cross-fertilisation of ideas also allows NGOs to learn, adapt and evolve their positions depending on the information needs of developing country delegates and the information that delegates can supply to international NGOs when they receive inputs from capital.

There is evidence that international NGOs listen to what they hear from delegates and respond accordingly. However, some delegates interviewed for the IP-NGOs project were concerned that it is difficult for NGOs to evolve because they are driven by the demands of their donors. International NGOs must be aware that delegates sometimes harbour these concerns. Nevertheless, international NGOs have worked hard to build a reputation of trustworthiness and, in general, delegates have good working relationships with them. Delegates have the confidence to approach international NGOs knowing that they can work with these groups in a way that is helpful to them. Nonetheless, the relationship between international NGOs and delegations on intellectual property issues can be improved further. The existing relationships are based mainly on contacts at the personal level. Contacts and relationships are not yet at an institutional level and this can undermine continuity when, for example, an individual working for an NGO leaves their post and is replaced by a new incumbent not known to, or trusted by, delegates.

\subsubsection{Temporary and issue-specific relationships between international NGOs and delegates}

The extent to which international NGOs provide advice on how to strategise and provide technical expertise to support developing countries during negotiations on policy-making and norm-setting in multilateral institutions changes depending on the issue concerned. In part this is because some developing countries have strong views on a particular issue, so the degree of interaction between international NGOs and delegates from developing countries tends to be temporary and issue-based in these instances. Other developing countries, for instance some large, middleincome developing countries, however, follow a broader range of intellectual property issues 
closely and in these latter cases the relationship between international NGOs and delegations may be of longer duration and cut across a range of issues.

Whether linkages between NGOs and delegates are short-term and issue specific or of longer duration and cutting across a range issues also depends on the particular international NGO involved, with some NGOs dealing with a range of intellectual property issues while others deal with specific topics such as access to medicines, farmers' rights, genetic resources and traditional knowledge. It is also the case that some international NGOs have engaged with intellectual property issues for relatively short and defined periods of time and have dropped out of the intellectual property debate once a decision is taken in a multilateral forum, for instance in relation to the Doha Declaration to the TRIPS Agreement and Public Health, moving on to other issues and not maintaining their relationships with delegates in the long-term.

Relationships between international NGOs and delegates also change depending on the intellectual property issues involved because different NGOs follow different issues in different forums, for example the CBD, the FAO International Treaty on Plant Genetic Resources for Food and Agriculture and the WIPO Intergovernmental Committee on Intellectual Property and Genetic Resources, Traditional Knowledge and Folklore (IGC). International NGOs involved with the WIPO Development Agenda may also be different from the groups involved with public health and access to medicines that were discussed in the WTO TRIPS Council because different NGOs prioritise different concerns. Institutional arrangements also matter with WIPO, for example, operating with country groupings that are not present in the WTO context and with international NGOs not able to participate to the same extent in the latter policy-making and norm-setting process.

\subsubsection{Relationships between international NGOs and delegates in different multilateral forums}

In many instances, the relationship between international NGOs and developing country delegations is further complicated by the fact that there are also different delegates acting as negotiators in different multilateral forums. A developing country, for instance, may well have one negotiator for the TRIPS Council and another for WIPO. There is a danger that this results in contradictory positions from the same country in different forums. The risks associated with this are particularly salient in relation, for example, to disclosure of origin issues, where the WTO, WIPO and the CBD-COP all play a role and this itself emphasises the coordinating role that NGOs play in bringing coherence within delegations. Where possible, continuity within delegations, with the same delegates attending TRIPS Council and WIPO meetings, for example, would assist in ensuring policy coherence without the need for the current level of assistance provided by international NGOs in this respect. Presently, however, international NGOs perform a useful role in facilitating improved policy coherence by developing countries on intellectual property issues by drawing together what is happening in various forums and also by drawing in government officials based in capital. In the latter respect, delegates frequently send briefing papers prepared by international NGOs back to capital, where they inform the policy debate at national level. The very fact that briefing papers prepared by international NGOs are sent back to capital in this way may indicate that international NGOs could engage more directly with capitals to assist government officials dealing with intellectual property issues in various policy-making contexts and to better inform the national policy process.

\subsubsection{Donors and international NGOs}

The funded activities agreed with donors can also have an impact on the relationships that international NGOs have with delegates to multilateral institutions. Some international NGOs are funded on the basis that their primary function is to support developing countries and, as such these international NGOs are more inclined to be responsive to what developing countries say they want to work on. Other international NGOs are more independent and are much less reliant on agendas being driven by developing countries. The degree of influence that developing countries have over the work undertaken by international NGOs depends therefore on the focus of a particular organisation, what their core activity is, and if they perceive themselves as primarily providing support to developing countries. 


\subsubsection{Role of experts}

It is impossible for international NGOs to have all the expertise that developing country delegates require in-house. A mixture of in-house and external expertise tends to be the norm. External experts, normally from academia, are often invited by international NGOs to provide policy advice by participating in workshops with delegates, prepare briefing papers, or be on hand to offer advice on an ad hoc basis and at specific events such as a WTO Ministerial Conference or the CBD-COP. These external experts are seen as adding value because NGOs often lack specialist expertise, or because what expertise international NGOs do possess is not of sufficient depth on particular issues. In this respect, experts are used by international NGOs because they provide technical advice and facilitate the process of information exchange and a greater understanding of the intellectual property issues. In terms of allocating resources, it is efficient also for international NGOs to use the expertise of academics to provide in depth studies that can inform discussions on intellectual property issues. Experts, normally from academia, provide a constant informal exchange of ideas and are perceived as acting in a similar way to experts at capital level who delegates might contact to ask a very specific question in order to be better prepared for a particular negotiation, the expert then responding with advice. Experts are frequently brought in by international NGOs but are not owned by any particular international NGO or even by the NGO community more widely - they are also consulted directly by delegates and the secretariats of multilateral institutions.

\subsubsection{Receptiveness of developing country delegates to international NGOs}

The degree to which developing country delegates are receptive to international NGOs also varies depending on the extent that a particular developing country feels that they need this input. However, even large, middle-income developing countries that receive substantial backup from capital are well aware that international NGOs can be useful because they can often articulate viewpoints that it would be politically or diplomatically unacceptable for developing country governments themselves to make. In this respect, even developing countries that do not depend on international NGOs can find these groups helpful to their interests, particularly because of the influence that these groups can have in the developed world in terms of public opinion and political agendas.

Overall, although the relationship between international NGOs and delegates varies from case to case, with the informal nature of these linkages making it extremely difficult to accurately evaluate their impact, international NGOs in general have helped developing countries in thinking about the issues and allowing them to utilise the expertise that international NGOs can provide. Delegates readily acknowledge the assistance they have received in this respect.

Specific examples of instances where international NGOs have provided advice and technical expertise to support delegates in their negotiations are: the Doha Declaration on the TRIPS Agreement and Public Health; the TRIPS Council deliberations on disclosure of origin of genetic resources; the WIPO IGC process; the CBD-COP consideration of disclosure of origin of genetic resources; the FAO International Undertaking on Plant Genetic Resources for Food and Agriculture; the World Health Assembly R\&D Treaty proposals; and the WIPO Development Agenda.

\subsubsection{Need for an inclusive approach}

However, international NGOs must avoid being perceived as excluding smaller developing delegations if they work predominantly with large, middle-income developing countries. Some delegates interviewed for the IP-NGOs project sensed that international NGOs were not including all delegations in their activities and were focusing instead on the larger delegations that were perceived as being more influential. An inclusive approach on the part of NGOs is important to ensure that delegations from smaller developing and least-developed countries are also involved in the networking activities of international NGOs. One type of coordination activity that delegates interviewed for the IP-NGOs project suggested in this respect was that international NGOs could meet regularly with groups of delegates, such as with the Asian Group, with the Group of Latin American Countries (GRULAC), or with least-developed countries (LDCs). Some delegates also 
felt that international NGOs should play a greater coordinating role among delegations in different multilateral institutions, engaging in more outreach to delegates that are not the principal players in order to make them aware of the importance of the issues and build a wider basis of support for policy proposals. The need for NGOs to make other delegations aware of what is happening in the negotiations and to broaden the discussion was raised by most of the delegates interviewed for the IP-NGOs project. Furthermore, while delegates valued the briefing documents they received from international NGOs, when interviewed for the IP-NGOs project they often felt that they had insufficient time to read all the briefings they are presented with, so these documents could usefully be augmented by regular meetings, workshops and seminars organised to summarise the main findings and recommendations of these briefing documents.

2.4.14 Differing relationships between international NGOs and developing countries: intellectual property and other issues

It is also the case that international NGOs have established close links with developing country delegates in a way that has not been seen in the context of other issues, such as environmental issues or human rights, where international NGOs have historically been perceived as critical of developing countries. In this sense, the work of international NGOs on intellectual property issues has had wider implications because it has led to less suspicion on the part of developing countries about international NGOs and has contributed to improved relationships. The intergovernmental organisation South Centre has also played an important role in bringing international NGOs and developing country delegates together.

\subsubsection{Preparing substantive policy inputs}

Typically, developing country proposals are prepared in consultation with international NGOs, and individuals representing NGOs are close to or, depending on the multilateral institution concerned, even inside the negotiating room. These international NGOs help delegates with strategic planning and analysis. This support helps delegates to make informed decisions. It improves the quality of delegates' positions, it increases the confidence of developing country delegations to oppose or support certain issues by showing that credible alternatives are available. It also makes developing countries more assertive in their views. However, international NGOs are not a substitute for intergovernmental decision-making. Some delegates interviewed for the IP-NGOs project felt that, on occasion, it is difficult to get neutral answers from international NGOs and that sometimes NGOs lose sight of their role and over-estimate what they can achieve. Where international NGOs try to play a more overtly political role, going beyond the provision of advice and technical expertise and advocating particular approaches too forcefully, this was not appreciated by delegates and was felt to be a reason why international NGOs might lose credibility in the future if they are not mindful of the need to be sufficiently even-handed in the ways that they present information to developing country delegates. Even-handedness will also allow delegates to be aware of counter arguments as well as the preferred policy positions of the international NGOs themselves.

Although there have been some anecdotal reports from those sceptical of the role of public interest NGOs, suggesting that this type of international NGOs write proposals for delegates without the latter fully understanding what this involves in policy terms, leading to a hiatus between the policy-making process because delegates cannot then sustain an argument in support of the proposals, the validity of this suggestion cannot be confirmed in the absence of substantive evidence that this actually occurs. Certainly, developing country delegates can be very receptive to advice and technical expertise from international NGOs and have come to view international NGOs as important sources of information of intellectual property issues, but developing country delegates are also pragmatic and view international NGOs as only one group of stakeholders that can be listened to and whose views should be taken into account.

\subsubsection{International NGOs, industry associations and rights holder groups}

Industry associations and rights holder groups, such as the International Federation of Pharmaceutical Manufacturers and Associations (IFPMA) and the American Biolndustry Alliance (ABIA), are also considered important sources of information and are listened to by developing 
country delegates. However, industry associations and rights holder groups were considered by delegates interviewed for the IP-NGOs project to be different from public action NGOs because the latter take into account human and societal considerations in a different way. In general, however, industry associations, rights holder groups and public action NGOs are all considered by delegates to be stakeholders. They differ to the extent that they have different perspectives on intellectual property.

Developing country delegates collect different inputs from different sources and there is careful thinking before decisions are taken on what position to adopt and, in many respects, international NGOs have been able to provide a counterweight to industry associations and rights holder groups that have had a traditionally stronger voice in, for example, the WIPO context. In this respect, the more recent engagement of international NGOs with intellectual property issues has played a significant role in helping delegates achieve a more balanced view in complex multilateral negotiations.

\subsubsection{Participation of international NGOs during meetings in multilateral institutions}

Delegates interviewed for the IP-NGOs project felt that international NGOs can often provide concrete evidence, for example on differential drug pricing or cases of alleged "biopiracy" and, in this respect NGOs are helping developing country delegates to advance policy debates. Statements made by international NGOs at WIPO meetings are also considered by delegates to be useful provided these NGOs do not abuse their position and seek to use the opportunity to publicise their own NGO activities instead of offering substantive inputs for the policy debate. However, whether the participation of international NGOs in multilateral forums influences policy outcomes is questionable. Some delegates interviewed for the IP-NGOs project felt that international NGOs should be trained how to make interventions in multilateral forums because they miss opportunities to communicate their positions as effectively as industry associations and rights holder groups, which tend to bring convincing arguments rather than simply opposing proposals in a general way.

\subsubsection{Limits to the relationship between international NGOs and developing country delegates}

Developing country delegates use different advice and technical expertise from different international NGOs and are pragmatic about what advice and technical expertise they find useful at particular moments in time. If the work of international NGOs is useful to delegates, they will use the advice and technical expertise made available to them, either on their own initiative or, where links with capital are well established and coherent, by sending information provided by international NGO back to capital where it can be considered and acted upon.

If there are differences between the positions being taken by international NGOs and by developing countries, there will be limits to the extent that delegates and capitals will follow the advice given by international NGOs. This is illustrated by the fact that, despite the close relationship that existed between international NGOs and developing country delegates on negotiations leading to the Doha Declaration on the TRIPS Agreement and Public Health on $14^{\text {th }}$ November 2001, developing country delegates did not follow the advice and technical expertise offered by international NGOs during negotiations leading to the $30^{\text {th }}$ August 2003 WTO Decision and the subsequent $6^{\text {th }}$ December 2005 agreement to amend the TRIPS Agreement in respect of public health imperatives.

But while developing country delegates value having multiple sources of information that provide systematic analysis of the issues, it is not necessarily the role of international NGOs to be the main providers of this information, as is often the case at present. Multilateral institutions themselves could do more to build capacity amongst delegations and to ensure the flow of information to developing country delegates and to government officials at capital level.

One particular issue of concern for some developing country delegates is that international NGOs focus on a limited range of issues, whereas governments must address and balance a range of interests and policy perspectives. But the relationship between international NGOs and delegates is still at an early stage and the relationship can and will evolve in the longer term. In particular, 
some delegates interviewed for the IP-NGOs project felt that, while NGOs have done good work on particular issues, such as public health and access to medicines or agriculture, genetic resources and traditional knowledge, more technical but equally important issues such as the Patent Cooperation Treaty (PCT), reform of which attracts relatively little attention from international NGOs.

\subsubsection{International NGOs and developing country governments at capital level}

At the national level within developing countries it is often more difficult for governments and NGOs to work together constructively than it is for delegates to work with international NGOs. When international NGOs engage with government officials at capital level, some government ministries are more receptive than others to the advice and technical expertise made available by international NGOs. At capital level the Ministry of Trade, for example, may have different policy priorities to the Ministry of Health. There may even be more than one point of view within the same Ministry. In this context it is instructive to note the issue-specificity of negotiations that take place at the CBD-COP or in the FAO process. Negotiations in these forums are limited to specific policy issues and this may account for the fact that some international NGOs perceive it as easier to liaise with developing country delegations there because wider trade issues (and hence government ministries driven by wider trade issues) do not predominate. Of course, national governments also change, so the relationship that developing countries have with international NGOs will always be in a state of flux.

For some developing countries, there is a disconnection between what is happening in multilateral institutions and what is happening in capital. There is a need for international NGOs to organise meetings and workshops at capital level to sensitise government ministers to the implications of intellectual property rights for development policy. Rather than organising these events on a piecemeal basis, the prospects for international NGOs enhancing their engagement with the intellectual property policy debate by establishing a greater number of national or regional offices in developing countries to link up delegates to multilateral institutions with officials in capital should be given serious consideration.

For developing countries, bilateral pressures and competing domestic interests need to be taken into account and international NGOs must remain mindful of the extent to which the advice and technical expertise they provide must be considered alongside other factors that may limit the extent that delegates are responsive to them. It is important that international NGOs recognise the pressures that delegates are under and respect their role as providers of advice and technical expertise in the intergovernmental process.

An ideal scenario would be one in which developing country governments undertake national consultations with different stakeholders in society (including NGOs, industry associations, intellectual property rights holders, trade unions and consumers). The outcome of those consultations could then provide inputs into the policy process so that governments can make informed decisions on intellectual property issues, those decisions then fed from capital level to delegates representing developing countries in multilateral institutions.

So far, international NGOs have had greater impact in terms of providing advice and technical expertise to delegates than to capital. The process of intellectual property policy-making and norm-setting would be enhanced if capital officials in a greater number of developing countries engaged more actively in policy-making and norm-setting activities that take place in multilateral institutions and it is a matter of some concern that, on occasion, delegates to multilateral institutions participate in intellectual property and norm-setting without sufficient input being provided from capital.

An important step towards remedying this dislocation between delegates and capital could be taken if international NGOs that have engaged so successfully in raising awareness of intellectual property issues amongst delegates to multilateral institutions, and subsequently providing advice and technical expertise, were to repeat this at capital level. Appropriate channels for the transfer of information from delegations to capitals may not be in place so international NGOs could usefully fulfil this role in ensuring that information transfer takes place. 
A related problem is how best to translate the agreements reached in multilateral institutions (such as the issuance of compulsory licences under the $30^{\text {th }}$ August 2003 WTO Decision) into action at the national level. Government officials in capital may well already have been exposed to traditional technical assistance providers from developed country governments, industry associations and rights holder groups. International NGOs would be well placed to provide officials in capital with different options and increasing the range of options to which officials in capital are exposed. This would facilitate informed decision-making on intellectual property policy in developing countries.

In recent years a number of international NGOs have begun to play a more technical role at capital level than they did previously, and have provided technical assistance to developing country officials in capital. International NGOs such as CPTech, TWN and Public Interest Intellectual Property Advisors (PIIPA) have undertaken work of this type, advising developing countries on technical matters at the domestic level, such as how to issue compulsory licences, while ICTSD has organised and participated in regional dialogues to disseminate policy-oriented research in developing countries and to inform and promote dialogue. However the role of international NGOs in providing technical advice and expertise in capitals has not been as prominent as the role of industry associations or rights holder groups that have frequently carried out capacity building activities focusing on implementation and enforcement of intellectual property rights. Undertaking more sustained work on the provision of advice and technical assistance at capital level should therefore be considered as a core activity by a greater number of international NGOs.

\subsubsection{Coordination of international NGOs}

Networks can assist in coordinating NGO inputs into intellectual property policy-making and norm-setting activities in multilateral institutions. The Civil Society Coalition (CSC), for instance, is a network of over thirty groups working in areas such as public health, agriculture, the development of free software, trademarks and domain names, copyright policy, the protection of non-copyrighted elements of databases, and the policies related to use of traditional knowledge, folklore and access to genetic resources. Consensus, however, can be difficult to achieve. CSC does not have a consensus position on issues relating to traditional knowledge due to the differing views of participating organisations.

International NGOs in multilateral forums also liaise in other ways. In Geneva, for example, IP coordination meetings have in the past been held every two or three months so that decisions can be taken on how best to divide activities depending on the mandates of different NGOs, with the aim of avoiding duplication. The IP coordination meetings are considered important in Geneva because each NGO has different strengths and because if one NGO does not have the spare capacity or the expertise to pick up a particular issue, others will do so. Representatives of CIEL, ICTSD, CPTech, QUNO, TWN and 3D attend IP coordination meetings. Although not NGOs, representatives of the intergovernmental organisations South Centre and the United Nations Conference on Trade and Development (UNCTAD) have in the past also attended these meetings. However, South Centre has recently decided that it will not participate in IP coordination meetings in the future.

At the time of writing, no IP coordination meeting of the NGO community in Geneva has been held for over six months. One possible reason for the relative absence of formal coordination activities amongst Geneva-based international NGO representatives recently is that donors funding international NGOs are increasingly targeting resources much more on activities with measurable outcomes than in the past. It is regrettable that formal coordination activities are becoming less frequent in the Geneva-based international NGO community at a time when some of the delegates interviewed for the IP-NGOs project indicated that they sensed a lack of coordination amongst the international NGOs and suggested that improved coordination would be welcomed, particularly if this reduced duplication and unnecessary overlaps when international NGOs engage with developing country delegates. 


\subsubsection{Raising public awareness}

International NGOs have also played an important role in raising public awareness of intellectual property issues. NGOs have helped the public to understand that intellectual property rights are important for health, education, food, and human rights. Their methods include: campaigning websites, newsletters, media and email alerts, sign-on declarations and letters circulated on the internet, and profile-raising awareness events. However, although valuable work to raise public awareness of intellectual property issues has been undertaken by international NGOs over the past five years, more awareness raising work is needed to highlight the continued significance of intellectual property rights for development policy. Delegates to multilateral institutions change frequently, so there is a constant need for renewal of intellectual property awareness amongst new incumbents. Public engagement on the part of electorates in developed countries can help to ensure that the debate on intellectual property rights and development policy remains high on the political agenda in those countries. In developed countries international NGOs have helped ensure that the public, politicians and government officials are now more aware of the impact of intellectual property rights on development policy. Similarly, greater awareness amongst the electorates of developing countries can help to ensure that developing country governments remain focused on the impact of intellectual property rights, for example, when negotiating the intellectual property provisions of free trade agreements.

As a result of the awareness-raising work that NGOs have undertaken, particularly over the past five years, politicians, policy-makers and the public are now more aware of issues related to intellectual property rights and their impact on developing countries. This is an important addition to the debate and acts as a counterbalance to the interests of producers and intellectual property rights holders. However there is limited capacity among the NGOs to take on issues and also limited capacity for the media and the public opinion to take in new issues highlighted by NGOs and there is still a need for on-going work of this type to be undertaken.

\section{Box 2}

\section{Summary of findings: international NGOs}

- International NGOs raise delegates' awareness of intellectual property issues. In this sense, NGOs act as an early warning system for developing country delegations.

- Delegates receive detailed advice and technical expertise from international NGOs that may not otherwise be available from capital.

- International NGOs assist delegates by improving their ability to understand the issues by preparing substantive papers. Delegates often send these papers back to government at capital level, where they are used to inform the policy debate.

- International NGOs are, and should remain, on the periphery of the intergovernmental policy-making and norm-setting process.

- International NGOs are facilitators. They try to increase coordination and interaction between NGOs and developing countries because they believe that dialogue is useful and worth promoting.

- The timing of advice and technical expertise provided by international NGOs to delegates is often crucial and it is important that representatives of international NGOs are on hand to assist developing countries. International NGOs with the resources to be present when meetings take place in multilateral institutions are best placed to fulfil this role.

- Developing country delegates value and trust the advice and technical expertise provided by international NGOs. Trust is built on personal relationships. 
- Cross-fertilisation of ideas with delegates helps international NGOs evolve and respond to the changing needs of developing countries. Ideally, the exchange of information between NGOs and developing countries should be a two way process.

- International NGOs must be mindful of the fact that, during the policy-making and normsetting process, developing country delegates are balancing negotiating positions on intellectual property issues with competing trade issues, domestic concerns and bilateral pressures. This may have implications for the positions that delegates are able to take.

- There is no evidence that developing country delegates have been captured by international NGOs. There is careful thinking before delegates take decisions on what position to adopt. Developing country delegates and capital officials see NGOs as only one stakeholder group whose views must the taken into account.

- The degree of influence that developing countries have over the work programmes of international NGOs depends on donor priorities, the focus of a particular NGO, what their core activities are and whether or not an NGO sees itself as primarily having the role of providing support to developing countries.

- Typically, international NGOs have expertise in-house but also use external experts, often from academia. These external experts are not owed by any particular NGO or even by the NGO community more widely.

- The process of intellectual property policy-making and norm-setting would be enhanced further if capital based officials were more aware of on-going discussions and developments and liaised more fully with delegations. On occasion this is not the case and delegates to multilateral institutions risk participating in intellectual property policymaking and norm-setting without sufficient input being provided from capital.

- The achievements of international NGOs in terms of raising awareness of intellectual property issues and then providing advice and technical assistance to developing country delegates to multilateral institutions needs to be replicated at capital level.

- Appropriate channels to transfer information from delegates to capital may not be in place. NGOs should play a more pronounced role in ensuring that the transfer of information takes place.

- Coordination amongst international NGOs is important. In Geneva, for example, IP coordination meetings enable each NGO to prioritise activities where they have particular strengths. However, delegates indicated to the IP-NGOs research team that improved coordination within the NGO community would be welcome to avoid duplication of effort.

- By mobilising the press and public opinion, international NGOs have raised awareness and helped to show that there are public interest aspects of intellectual property issues in multilateral institutions that need to be taken into account. 


\section{FINDINGS: SOUTHERN NGOS, SOCIAL MOVEMENTS, INDIGENOUS GROUPS AND LOCAL COMMUNITIES}

3.1 Southern NGOs, social movements, indigenous groups and local communities falling within the scope of the IP-NGOs project

Box 3, below, provides examples of international NGOs falling within the scope of the IP-NGOs project.

\section{Box 3}

Examples of Southern NGOs, social movements, indigenous groups and local communities falling within the scope of the IP-NGOs project

Assessoria e Serviços a Projectos em Agricultura Alternativa (AS-PTA); Biowatch; Centro de Educación y Tecnología para el Desarrollo del Sur (CET-Sur); Community Biodiversity Development and Conservation Programme (CBDC); Comunidad local de Seringueros; Cooperativa de mujeres estrativistas (CEMEN); Delhi Science Forum; Gene Campaign; Instituto Mayor Campesino (IMCA); Jana Swasthya Abhiyan (JSA); National Working Group on Patent Law (India); Navdanya; the South African San Institute (SASI); Treatment Action Campaign (TAC); Via Campesina.

\subsection{Southern NGOs and multilateral institutions}

Historically, international NGOs with the highest profile on intellectual property issues in multilateral institutions have tended to be from the North. Notable exceptions are TWN, an international NGO from the South that has a strong presence in multilateral forums; HAl, which has been an important as a network for health activists and developing country activist groups; and Focus on the Global South which, although not dealing specifically with intellectual property issues has nonetheless been an important NGO in relation to wider global trade issues.

Many Southern NGOs working on intellectual property issues are also undertaking good and effective work at the national, regional, or sub-national level, but their activities are not widely acknowledged because they do not have an international profile. There is also a discernable trend for Southern NGOs to work together with international NGOs, when financial support or advice and technical expertise are deemed appropriate.

\subsection{Case study summary: Public health and access to medicines}

It was not only international NGOs but also activists in developing countries that were an important catalyst in making explicit the link between intellectual property, public health and access to medicines. The potential impact of TRIPS was brought sharply into focus on $1^{\text {st }}$ March 2001, when 39 global pharmaceutical companies, represented by the Pharmaceutical Manufacturers Association of South Africa, brought an action before the High Court of South Africa (Transvaal Provincial Division) objecting to provisions of the South African Medicines Act that gave the Health Minister the power to grant compulsory licences for patented pharmaceutical products when public health was at stake. In highlighting the implications of this case and the relationship between patents and access to anti-retroviral drugs, the South African NGO Treatment Action Campaign (TAC), supported by legal expertise provided by academics based at Wits University working as the Aids Law Project, played a crucial role.

The same month as the South African court case, on $7^{\text {th }}$ March 2001, Brazilian HIVIAIDS organisations, including Grupo de Incentivo à Vida (GIV) and the Associação Brasileira Interdisciplinar de AIDS (ABIA), began public demonstrations in front of US consulates in Brazil in order to bring attention to WTO dispute settlement proceedings initiated by the United States against Brazil. The dispute, related to the compulsory licensing provisions of Brazilian legislation and, although a mutually satisfactory solution was reached in June 2001to end the dispute, since 
then NGOs in Brazil have continued to highlight the potential of compulsory licensing to reduce prices and increase access to anti-retroviral drugs for people living with HIV. ABIA participates in the intellectual property working group of the Rede Brasileira pela Integração dos Povos (REBRIP), a network that monitors the liberalization of trade and its impacts in Brazil and other countries of southern hemisphere. The NGO Instituto de Direito do Comércio Internacional e Desenvolvimento (IDCID), comprising academics based at the University of São Paulo Law School, also provides technical inputs on intellectual property issues, while the international NGO MSF is also active in Brazil.

In India, where reform of the Patent Act of 1970 has been a high profile issue for the over a decade, a number of groups have played an important role in highlighting the link between intellectual property and access to medicines. The National Working Group on Patent Law, for instance, which has links with the international NGO MSF, is an informal public interest expert group in India. The National Working Group on Patent Law has provided substantive inputs into the policy-making process through participatory communication channels such as the Parliamentarian Forum and has assisted with public understanding of patent law reform by convening People's Commissions on Patent Laws for India, four of which have been convened so far. The Lawyers Collective HIVIAIDS Unit, supported initially by funds from the European Commission and more recently by the Swedish International Development Agency (SIDA) is now also playing an important role, in collaboration with MSF, undertaking third party pre-grant opposition in relation to the issuance of patents for pharmaceutical products.

The activities of NGOs in South Africa, Brazil and India have not only focused attention on the significance of intellectual property at a national level. They have also galvanised public opinion globally and, crucially, have provided important inputs into the work of international NGOs dealing with delegates to multilateral institutions.

\subsection{Case study summary: Agriculture, genetic resources and traditional knowledge}

The role of formally constituted NGOs in the South must also be considered alongside activities undertaken by wider forms of public action. For the IP-NGOs project this is particularly notable in relation to agriculture, genetic resources and traditional knowledge, where social movements, such as farmers' groups, indigenous groups and local communities are extremely knowledgeable and effective in communicating their concerns about the adverse implications of intellectual property rights. In this respect, groups in Latin America such as Via Campesina, Instituto Mayor Campesino (IMCA) in Colombia, Centro de Educación y Tecnología para el Desarrollo del Sur (CET-Sur) in Chile and their global partners in the Community Biodiversity Development and Conservation Programme (CBDC) have all made important contributions at the grassroots level.

Social movements and farmers' groups not formally constituted as NGOs also play an important role in mobilising grassroots activism in India. The Delhi Science Forum, part of the All India People's Science Network, and Jana Swasthya Abhiyan (JSA), a network of organisations, women's networks, health networks, smaller organisations working on specific health issues, trade unions, and medical associations of India are founding organisations of the People's Health Movement. Much of the information disseminated by the Delhi Science Forum and the JSA originates from the work of the National Working Group on Patent Law, discussed in section 3.3.

Often these movements at grassroots level work in tandem with NGOs. In Brazil, the NGO Assessoria e Serviços a Projectos em Agricultura Alternativa (AS-PTA) has worked with farmers' groups on intellectual property issues associated with farmers' rights, seeds and biodiversity since the 1980s. In India, the Gene Campaign and Navdanya are NGOs that work with farmers' groups and local communities on issues relating to agriculture, genetic resources and traditional knowledge for a number of years. International NGOs such as ETC, the GAIA Foundation, GRAIN and Practical Action have also provided valuable support for grassroots movements, as well as for NGOs, in developing countries.

In South Africa the South African San Institute (SASI), through its work with the San peoples on access and benefit sharing (ABS) agreements relating to patenting and commercialisation of products derived from the succulent Hoodia gordonii, demonstrates how NGOs can work at the 
grassroots level. In the case of Hoodia gordonii, the initiative to achieve an ABS agreement was supported by technical expertise from the South African NGO Biowatch (which itself received assistance from the international NGO ActionAid) and by the Legal Resources Centre which provides advice and technical expertise to support rights of indigenous people to their land and to facilitate access to anti-retroviral drugs amongst local communities in South Africa.

In Latin America, activists from grassroots social movements such as Cooperativa de mujeres estrativistas (CEMEN), a cooperative of about 200 women workers (estrativistas) living in protected areas of the State of Pare in Brazil, representatives of which attended the CBD-COP 8 meeting in Curitiba in March 2006, are also extremely knowledgeable on issues of biodiversity. Although the interaction of small grassroots groups such as CEMEN with intellectual property issues is not widely acknowledged, this group has in-house technical expertise on intellectual property issues through its own project specialists and lawyers and is ready and willing to participate directly in discussions and negotiations on intellectual property issues in multilateral forums, provided that funding is made available to facilitate this.

\subsection{Analysis: Engagement of Southern NGOs, social movements, indigenous groups and local communities with intellectual property issues in multilateral institutions}

\subsubsection{Direct participation}

For groups such as CEMEN, direct participation is seen as preferable to relying on their viewpoints being articulated by international NGOs seeking to speak on their behalf and it must be acknowledged that some grassroots groups are distrustful of international NGOs, the perception of these groups being that NGOs are seeking to attract funding from donors by claiming to represent the interests of local communities even when they have no mandate to do so. Instead, many social movements, indigenous groups and local communities would prefer capacity building initiatives to enable them to represent their own interests, with funding provided for travel and subsistence to allow them to participate in meetings organised by multilateral institutions.

\subsubsection{Infrastructure}

Deficiencies in basic infrastructure can also be a barrier to participation by local groups. For groups representing Brazilian local communities such as Comunidad local de Seringueros and others from the State of Acre in Brazil, while there is a great deal of awareness of issues concerning traditional knowledge, there is also a recognition that lack of access to basic communication resources such as telephones, postal services, the internet, or even electricity is hindering their communities' ability to engage with discussions and negotiations on intellectual property rights, despite their grassroots knowledge and experience of the issues involved.

\subsubsection{Networks and coalitions}

Networks and coalitions can partially alleviate the problem of groups in the South not having direct representation at meetings organised by multilateral institutions and there is some evidence that there are increasing levels of dialogue and coordination between international NGOs and groups in the South in order to achieve this. The dialogue and coordination between international NGOs and Southern NGOs, social movements, indigenous groups and local communities is achieved through list servers, joint work, research papers and related activities. However, the issue of structural barriers in the form of lack of access to basic communication resources must be borne in mind and all parties must continue to work hard to improve these linkages and relationships. Much of the discourse on the impact of intellectual property rights also often requires knowledge of English, making language a barrier to engagement with intellectual property policy-making and norm-setting in multilateral institutions.

That said, where access to the internet is available and language is not a barrier, the degree of dialogue and coordination has increased in recent years as different groups have become adept at networking and using the internet effectively. To this extent, while lack of resources and language barriers continue to be issues that hinder the ability of Southern NGOs, social 
movements, indigenous groups and local communities to engage with debates and negotiations on intellectual property issues in multilateral institutions, if coordination can be established and barriers overcome, these groups can become very effective alongside their counterparts in the international NGO community.

The effectiveness of Southern NGOs, social movements, indigenous groups and local communities is particularly notable when it enhances evidence-based arguments and engaging with these groups enhances the inputs of international NGOs that are able to attend meetings on intellectual property issues in multilateral forums.

\subsubsection{Funding}

Furthermore, even where Southern NGOs, social movements, indigenous groups and local communities are knowledgeable and active at the national, regional or sub-national level, these groups rarely have the resources to attend meetings in multilateral forums. Donors rarely make provision to allow groups to participate in multilateral forums. There are some notable exceptions to this. The CBD-COP 8 in Curitiba, for instance, included numerous representatives of NGOs, social movements, indigenous groups and local communities, the travel (though not necessarily subsistence) costs for whom was provided by the Brazilian Federal Government, while the WIPO IGC process funds participation by many of the 139 accredited organisations, over half of which are indigenous or local communities.

While these initiatives are laudable and well thought of by participating groups, the lack of financial resources to enable Southern NGOs, social movements, indigenous groups and local communities to engage directly with intellectual property issues being discussed and negotiated more widely at the plethora of meetings organised by multilateral institutions remains a major issue for many of the groups interviewed for the IP-NGOs project. Groups in the South often feel that donors were reluctant to fund their work at an international level, which leaves them with resources to play a role only at a regional, national or sub-national level. While some Southern NGOs, social movements, indigenous groups and local communities are not interested in playing a role at an international level, seeing their main focus as being at a regional, national or subnational level because this was the most efficient use of their resources, other groups interviewed for the IP-NGOs project expressed a real desire to be consulted more fully than at present and to participate directly in discussions and negotiations taking place in multilateral institutions.

\subsubsection{Regional consultations and public hearings}

One option that could alleviate demands for increased funding to bring more groups to meetings organised by multilateral institutions would be for those institutions to make greater use of outreach activities such as regional consultations and public hearings. Examples include the open forum event, held in Geneva in March 2006 to consider the draft WIPO Substantive Patent Law Treaty, regional consultations held in Latin America to consider the draft WIPO Broadcasting Treaty, and hearings held in various developing country locations by the WHO Commission on Intellectual Property Rights, Innovation and Public Health (CIPIH). During the CIPIH process interested parties were asked to submit documents, representatives from NGOs were invited people to speak at meetings in Geneva and at the national level where the Commission met with stakeholders (in South Africa, Brazil and India). For the CIPIH the regional meetings were important in terms of increasing the understanding of the issues and informing the debate on intellectual property and public health. In some countries the CIPIH met with NGOs in separate meetings to those with government, particularly when governments were not enthusiastic about the CIPIH meeting with NGOs in those countries. By ensuring that non-State actors such as Southern NGOs, social movements, indigenous groups and local communities are able to participate in consultations and hearings in these ways, the participatory nature of the consultation process could be enhanced considerably.

The proposal, contained in the annex of WIPO Provisional Committee for the Development Agenda document PCDA/2/2 of 23 June 2006, for WIPO norm-setting activities to be preceded and effectively guided by debates and public hearings with open participation by all membercountries and all stakeholders, should be borne in mind in this respect. Outreach on the part of 
multilateral institutions in the form of consultations and public hearings, particularly when these events are held regionally in developing countries, have considerable potential to enhance the policy-making and norm-setting process further.

Greater recourse to regional consultations and public hearings should be given serious consideration in the future. Such events must be inclusive of the views of Southern NGOs, social movements, indigenous groups and local communities and should not focus only on engagement with government representatives. The WHO CIPIH provides a useful model in this respect. However, it must be acknowledged that developing countries are at times sensitive about enhancing the participation of some stakeholders due to the perceived implications for claims for land rights or because some of these groups may have been critical of government policy in the past, for example, in relation to policies on the provision of anti-retroviral drugs to people living with HIV. Multilateral institutions should be mindful of these sensitivities and adopt strategies to ensure engagement with all stakeholders, even where governments may be inclined to adopt a gatekeeper role, restricting access to the consultation process.

\subsubsection{Technical knowledge and capacity building}

To some extent, however, the issue is not simply one of whether or not Southern NGOs, social movements, indigenous groups and local communities that are active at the national level should be physically present in multilateral forums or regional consultations and hearings. A physical presence is not enough for developing country NGOs. Nor is it sufficient to encourage these groups to make declaratory statements at the beginning or the end of meetings of multilateral institutions. Empowering Southern NGOs, social movements, indigenous groups and local communities with technical knowledge and the capacity to engage with debates in a meaningful way is also crucial.

As well as empowering these groups to participate themselves, delegates to multilateral institutions and government officials at capital level who are working on intellectual property issues on a day-to-day basis also need support from people and organisations that are knowledgeable on the technical aspects and who can give hands-on advice and can engage with the substance of the debate. Few Southern NGOs, social movements, indigenous groups and local communities possess this of depth knowledge or the training to articulate their arguments in a policy-oriented way and a great deal more could be done in terms of capacity building, improving the stock of technical knowledge on intellectual property issues in Southern NGOs, social movements, indigenous groups and local communities to assist them to contribute to the policy debate in a constructive way.

Some Southern NGOs, social movements, indigenous groups and local communities interviewed for the IP-NGOs project also expressed concern that international NGOs do not have a sufficiently clear view of what is happening in the regional, national and sub-national contexts to convey accurate messages on the impact of intellectual property rights on development policy in multilateral forums. In particular, there was concern that it is not sufficient for NGOs to organise workshops to engage with Southern NGOs, social movements, indigenous groups and local communities on a piecemeal basis, and that new, more dynamic ways of working collaboratively with Southern NGOs in a systematic manner should be sought out and utilised in the future.

\subsubsection{Relations with developing country governments}

While relatively few Southern NGOs, social movements, indigenous groups and local communities have engaged with debates and negotiations on intellectual property issues at meetings organised by multilateral institutions, many have focused on issues at a regional, national, or sub-national level. Here, on occasion, these groups have played an important role interfacing with government officials at the national, regional or sub-national level. This has been important in terms of matching the work that international NGOs have been undertaking with delegates by establishing and maintaining links with government officials in capitals. It is often the case that additional work needs to be done by liaising with government officials at capital level, where there is often a lack of information and expertise on intellectual property issues. This further work should be not only in terms of raising awareness of the issues, but also in terms of 
the provision of technical information on the policy options available so that government officials in capital can then respond to these issues in the most appropriate way. However, it is not always easy for Southern NGOs, social movements, indigenous groups and local communities to have access to officials dealing with intellectual property issues at capital level. Governments are not always structured in a way that is open to new information sources.

The impact of Southern NGOs, social movements, indigenous groups and local communities may differ from that of international NGOs because the former may have an uneasy relationship with policy-makers at the national, regional and sub-national levels and can be perceived to be critical of developing country governments in a way that international NGOs interfacing with delegates on intellectual property issues in multilateral institutions are frequently not.

There is great potential for Southern NGOs, social movements, indigenous groups and local communities in larger, middle-income developing countries such as India and Brazil (and in Latin America more generally) that are knowledgeable and experienced on issues such as access to anti-retroviral drugs for people living with HIV, farmers' rights, genetic resources and the traditional knowledge of indigenous peoples to engage in South-South technical assistance to assist their counterparts in other developing countries to address issues relating to intellectual property policy-making and norm-setting. In the global South more generally, however, there is a relative absence of groups working on issues relating to intellectual property rights.

South Africa is a special case in this respect because, post-apartheid, many previously wellinformed and effective activists have taken up employment in government and the resultant vacuum in the activist movement has yet to be filled. In some other developing countries, groups tend not yet to be knowledgeable about intellectual property and have still to acquire the specialist knowledge on intellectual property rights that would enable them to engage with these issues effectively.

In addition to lack of resources to facilitate dialogue building and coordination activities, particularly in parts of sub-Saharan Africa, NGOs, social movements, indigenous groups and local communities often lack technical expertise on intellectual property issues to an extent that is not the case in Latin America, for example, and this is a particular issue for future governance in the African context. 


\section{Box 4}

Summary of findings: Southern NGOs, social movements, indigenous groups and local communities

- There is evidence of Southern NGOs, social movements, indigenous groups and local communities undertaking good and effective work at the national, regional, or sub-national level, but their activities related to intellectual property policy-making and norm-setting are not widely acknowledged because they tend not to have an international profile.

- Networks and coalitions can partially alleviate the problem of groups in the South not having direct representation at meetings organised by multilateral institutions and there is some evidence that there are increasing levels of dialogue and coordination between international NGOs and groups in the South in order to achieve this.

- Structural barriers in the form of lack of access to basic communication resources must be borne in mind. Deficiencies in basic infrastructure can also be a barrier to engagement for local groups. All parties must work to improve these linkages and relationships.

- The effectiveness of Southern NGOs, social movements, indigenous groups and local communities is particularly notable in terms of enhancing the evidence-based arguments of international NGOs that attend meetings on intellectual property issues in multilateral forums.

- With some notable exceptions, there is a relative absence of Southern NGOs, social movements, indigenous groups and local communities that are working on issues relating to intellectual property rights.

- Even where Southern NGOs, social movements, indigenous groups and local communities are knowledgeable and active at the national, regional or sub-national level, these groups rarely have the resources to attend meetings in multilateral forums. Donors rarely make provision to allow groups to participate in multilateral forums, although there are some notable exceptions to this, including the CBD-COP and the WIPO IGC process.

- In the longer term, it is not sufficient for international NGOs that are present in multilateral forums to represent the interests of Southern NGOs, social movements, indigenous groups and local communities. Mechanisms need to be established to allow these groups to represent themselves.

- While initiatives thus far undertaken to ensure the direct participation Southern NGOs, social movements, indigenous groups and local communities in intellectual property policymaking and norm-setting are laudable and well thought of by participating groups, the lack of financial resources to enable these groups to engage directly with intellectual property issues being discussed and negotiated more widely remains an issue of concern.

- One option that could alleviate demands for increased funding to bring more groups to meetings organised by multilateral institutions would be for the secretariats of those institutions to make greater use of outreach activities such as regional consultations and public hearings. Greater recourse to regional consultations and public hearings to elicit the views of groups from the South should be utilised in the future. 


\section{FINDINGS: RELATIONS BETWEEN PUBLIC ACTION NGOS AND INDUSTRY}

There is a certain degree of professional respect between representatives of public action NGOs and their industry counterparts but collaboration to achieve common goals, for example, improvements to public health, through dialogue and coordinated action has thus far not occurred to any great degree, with relatively low levels of interaction between public action NGOs and industry groups identified by interview respondents for the IP-NGOs project. Instead, one of the main consequences of NGO engagement with intellectual property issues in multilateral institutions for industry associations have tended to be in terms of acting as a counterbalance to industry and rights holder groups, for instance in the context of WIPO where the latter have traditionally played a higher profile role, with public action NGOs relatively absent until five years or so ago. Historically, industry associations and rights holder groups such as the International Federation of Pharmaceutical Manufacturers and Associations (IFPMA) and the International Chamber of Commerce (ICC) have had more engagement with intellectual property policymaking and norm-setting at multilateral institutions than have public interest NGOs.

Nevertheless, from industry's point of view there is also recognition that, it cannot afford to ignore the work being undertaken by public action NGOs because of the impact this can have on the prevailing discourse on intellectual property rights. Conversely, it also remains important for public action NGOs to talk to industry in order to understand their positions, the constraints that industry operates under and their thinking. Public action NGOs must make its arguments to industry convincingly and in a systematic way, and understanding industry's point of view can assist greatly in this respect. There is consequently great potential to explore the possibilities for enhanced interaction between public action NGOs and industry associations and rights holder groups to yield mutually desirable outcomes.

It should also be noted, however, that the picture of interaction between public action NGOs and industry differs depending on which public action NGOs, industry groups and companies involved. For example, leaving aside industry and rights holder associations, when dealing directly with small, specialised, research and development (R\&D) pharmaceutical companies and the generic drug industry, representatives of public action NGOs interviewed for the IP-NGOs project highlighted more substantial dialogue than with large R\&D pharmaceutical companies.

In the case of larger R\&D pharmaceutical companies, one problem identified by public action NGO representatives interviewed for the IP-NGOs project was that, when they do invite industry representatives to engage in dialogue it is not the key decision makers in industry who attend, but rather lobbyists or lawyers who lack the authority or seniority to take a more considered view and instead resort to simply restating well-known and established industry positions.

Industry representatives, on the other hand, have expressed concerns that when they are invited to participate in meetings organised by public action NGOs, they are there primarily to legitimise the pre-determined positions of those NGOs rather than any attempt to listen to the industry viewpoint.

For dialogue to work, both parties must ensure that representatives of groups associated with the counter viewpoint are not simply there as token representation. This results in the entrenchment of well-known positions on both sides and is not meaningful dialogue in any real sense because each side comes to discussions with a fixed position already in place.

But public action NGOs engage with industry to different degrees. Oxfam, for example, has undertaken work on specific companies, such as its Briefing Paper on Pfizer entitled "Preventing the Cure: corporate lobbying and fair access to medicines" and its Briefing Paper on GlaxoSmithKline entitled "Dare to Lead: public health and company wealth". MSF, on the other hand, has a different relationship with the R\&D pharmaceutical industry because, while it challenges industry practices constantly as part of its Campaign for Access to Essential Medicines, industry also recognises that MSF is a significant customer of its products so it is well placed to maintain a sustained dialogue with the pharmaceutical industry on issues of access to medicines. 
There is also a relatively recent trend for well-established pro-industry think tanks to engage with intellectual property issues in order to rebut the work of public action NGOs. The American Enterprises Institute for Public Policy Research and the Hudson Institute were mentioned by representatives of public interest NGOs interviewed for the IP-NGOs project as are examples of these think tanks, while new industry groups are also being set up, such as the American Biolndustry Alliance $(A B I A)$ that provides a counterview on disclosure of origin for genetic resources.

One positive example of engagement between public action NGOs and industry is worthy of particular note. NGOs dedicated to the establishment of public private partnerships (PPPs), such as the Drugs for Neglected Diseases Initiative (DNDi) and the Medicines for Malaria Venture (MMV), have good relations and frequent dialogue with industry because they need to maintain these links in order to be successful in their PPP ventures to promote research into new drugs to address neglected diseases for the benefit of developing countries.

\section{Box 5}

\section{Summary of findings: relations between public action NGOs and industry}

- Despite a certain degree of professional respect, common goals are not emphasised and there are relatively low levels of interaction between public action NGOs and industry groups.

- Public action NGOs counterbalance industry and rights holder groups in multilateral forums, for example in the context of WIPO where industry and rights holder groups have traditionally played a role but where public action NGOs were in the past absent.

- Industry cannot afford to ignore the work being undertaken by public action NGOs because of the impact this can have on the prevailing discourse on intellectual property rights.

- Conversely, it also remains important for public action NGOs to talk to industry in order to understand their positions, the constraints that industry operates under and their thinking.

- At present, when public action NGOs invite industry representatives to engage in dialogue, there are concerns that it is not the key decision makers in industry who attend, but rather lobbyists or lawyers who lack the authority or seniority to take a more considered view and instead resort to simply restating well-known and established industry positions.

- Industry representatives, on the other hand, have expressed concerns that when they are invited to participate in meetings organised by public action NGOs, they are there primarily to legitimise the pre-determined positions of those NGOs rather than any attempt to listen to the industry viewpoint.

- For dialogue to work, both parties must ensure that representatives of groups associated with the counter viewpoint are not simply there as token representation. This results in the entrenchment of well-known positions on both sides and is not meaningful dialogue in any real sense because each side comes to discussions with a fixed position already in place.

- Public private partnerships for neglected diseases are an example of positive relations between public action NGOs and industry. 


\section{FINDINGS: ARRANGEMENTS FOR NGO ENGAGEMENT WITH MULTILATERAL INSTITUTIONS}

While it is not the intention of this report to set out the detailed arrangements for NGO engagement with intellectual property policy-making and norm-setting activities in multilateral institutions, a number of common characteristics and differences between the approaches taken by the various institutions should be considered. These are set out below.

\section{$5.1 \quad$ WTO}

As regards current arrangements for NGO participation in the WTO, NGOs receive information but there is no accreditation process except for the bi-annual Ministerial Conferences. These Ministerial Conferences, however, are not the main meetings as regards decision-making on intellectual property issues. NGOs cannot attend the regular TRIPS Council meetings where this decision-making primarily takes place. NGOs can also send materials to the WTO Secretariat and to the Dispute Settlement Body, but there is no obligation on the part of the WTO to take these materials into account. As such, there is no formal relationship between NGOs and the WTO, which remains a Member-driven institution. The annual WTO Public Forum provides an additional mechanism for engagement with NGOs, although the WTO Secretariat has no mandate for this. WTO Members should consider initiating a review of current arrangements for NGOs, which date back to the WTO Agreements of 1994, with a view to enhancing arrangements in the future. Nevertheless, in practice, alongside formal WTO mechanisms for engagement with NGOs, there is also constant informal dialogue between NGOs and the WTO Secretariat on intellectual property issues, with information shared in a way that informs the policy-making and norm-setting process by assisting delegates in their capacity to negotiate.

\section{$5.2 \quad$ WIPO}

WIPO has a long history of NGO participation but is nonetheless still evolving in terms of its relatively recent relationship with public action NGOs. This is because, until three or four years ago, non-Member representatives attending WIPO meetings were almost exclusively industry and rights holder groups, categorised as NGOs. In this respect, the increasing interest of public action NGOs is a relatively new phenomenon. Even those few public action NGOs accredited by WIPO prior to this, such as ActionAid, did not to attend WIPO meetings regularly. In the last three or four years, however, the level of public interest NGO involvement has increased dramatically and, although there has been a perception that WIPO is more prone to contacts with industry associations and rights holder groups than with public action NGOs, that perception is largely historical. In terms of present day WIPO arrangements for engagement with NGOs, representatives of public action NGOs interviewed for the IP-NGOs project generally felt that WIPO has a good system and recognised that, in the past, public action NGOs had perhaps not followed the issues as closely as industry associations and rights holder groups.

WIPO has a formal structure that allows for the participation of NGOs in its policy-making and norm-setting activities. NGOs can apply for accreditation to enable them to attend meetings and make statements and they also receive informal briefings from staff of the International Bureau. Although WIPO is flexible in terms of NGO participation, Members remain the priority. NGOs can participate in different WIPO standing committees and other non-permanent committees, however these committees remain intergovernmental and thus Member-driven. It is in the Intergovernmental Committee on Intellectual Property and Genetic Resources, Traditional Knowledge and Folklore (IGC) and the Provisional Committee on the Development Agenda (PCDA) that public action NGOs have been particularly active. Further consideration is given to NGO engagement with intellectual property policy-making and norm-setting activities in these two forums below.

The IGC has been particularly notable in its efforts to allow for the greater participation not only of NGOs but also of indigenous groups and local communities in the policy-making and norm-setting process. The IGC grew out of a new programme, which commenced in 1998 and was aimed at communities that had been marginalized (which became known as "IP beneficiaries"). The project involved two years of visits to indigenous groups and local communities to ascertain their needs. 
The project resulted in the WIPO Report on Fact-finding Missions on Intellectual Property and Traditional Knowledge (1998-1999) entitled "Intellectual Property Needs and Expectations of Traditional Knowledge Holders", published in April 2001, which subsequently became the basis for activities. NGOs and indigenous groups had a direct input in the design and implementation of the IGC programme, although it was still criticised for not being universal. Developing countries also sought to increase the protection of traditional knowledge and this led to the creation of the IGC. The IGC has adopted an open approach to NGO accreditation and there are now over 139 NGOs accredited to the IGC. No NGO has so far been refused accreditation. In the IGC, which is currently working on two drafts of a possible international instrument for the protection of traditional knowledge, NGOs and indigenous groups participate alongside Members. Proposals made by NGOs and indigenous groups are included in draft documents, with the intention of reducing barriers for indigenous groups to provide inputs into the policy process. In addition, IGC meetings commence with an indigenous representative chairing the meeting to instruct delegates of their needs and interests. A further concern was that indigenous groups would lack sufficient funding to participate in the IGC. To address this concern, a Voluntary Fund for Accredited Indigenous and Local Communities has been set up. However, it should be noted that some NGOs that have participated previously in meetings of the IGC have recently decided to stop attending the meetings because of lack of progress in terms of policy outcomes. Identifiable outcomes, as well as participatory processes, are crucial for the success for any multilateral institution.

With regard to the PCDA, in addition to the NGOs accredited to attend meetings, the WIPO Secretariat has also made efforts to engage, for example, by organising a separate NGO meeting on the Development Agenda process in 2005. However this was a one-off, Geneva-based event and was poorly attended by NGOs. Greater resources could be allocated to consultation meetings of this type on a regional basis in order to be inclusive of NGOs, social movements, indigenous groups and local communities in developing countries. The PCDA process is ongoing and has thus far considered engagement with NGOs through a number of detailed proposals. Annex I of document PCDA/1/6/ Prov.2, for instance, contained the proposal "to formulate and adopt measures designed to improve participation by civil society and other stakeholders in WIPO activities, relevant to their respective domains and interests". It also contained proposals "to undertake measures to ensure wider participation of civil society and public interest groups in WIPO's activities". Further consideration of WIPO arrangements for engagement with NGOs will be on the agenda at subsequent PCDA meetings, scheduled for 2007.

\section{$5.3 \quad \mathrm{WHO}$}

WHO has an established system for engagement with NGOs, with accredited NGOs permitted to attend and to make statements in meetings. In addition, as noted above, the endeavours of the CIPIH to engage with NGOs and other stakeholders in developing countries may provide a useful model for outreach, consultation and engagement with non-governmental interests in developing countries in the future. A further recent initiative, in November 2006, has been the fact that the WHO Intergovernmental Working Group on Public Health, Innovation and Intellectual Property was preceded by web-based public hearings, in which the WHO encouraged individuals, civil society groups, government institutions, academic and research institutions, the private sector and other interested parties to contribute evidence. The use of web-based consultations as a mechanism for future consultation with stakeholders should be reviewed and evaluated in the light of this experience.

\section{$5.4 \quad$ CBD-COP}

The CBD-COP is relatively open to participation by NGOs. In the Ad Hoc Working Group on Access and Benefit Sharing (ABS) of the CBD NGOs can present documents and are allowed to participate when the meetings take place. NGOs can also engage informally at many levels with the CBD Secretariat. At the formal level there is a need to align the CBD processes for NGO engagement with existing ad-hoc processes. The accreditation process is currently being considered by the CBD Secretariat which, in March 2006, made a proposal to the CBD-COP 8 (Draft Policy for the Accreditation of NGOs to the CBD, document UNEP/CBD/COP/830). This was treated with caution by NGOs at the COP 8 meeting, given that it proposed more formal 
arrangements for NGO accreditation to a CBD process that has traditionally been very open. Public action NGOs are also concerned about the way the terminology of "NGO" is being used in the CBD-COP context, NGOs arguing for separate categories of accreditation for industry, indigenous groups and local communities. Social movements such as Via Campesina, which staged peaceful demonstrations at CBD-COP 8, have also called for greater participation in the policy-making and norm-setting process. At present, the CBD Secretariat funds the participation only of developing country delegates, so many public action NGOs, social movements, indigenous groups and local communities from developing countries lack the resources to be able to attend CBD-COP meetings, particularly if these are outside the geographical region in which they operate. The CBD-COP is considering measures to formalise accreditation, but was unable to conclude these deliberations at CBD-COP 8.

\section{$5.5 \quad F A O$}

In the FAO the agenda on intellectual property rights-related issues relates closely to the work of the Commission on Genetic Resources for Food and Agriculture (CGRFA), which was set up in 1983 as a forum for governments to address questions related to access and benefit sharing (ABS) on plant genetic resources for food and agriculture. Operating under a multi-stakeholder model, the CGRFA includes representatives from NGOs, academia, business and farmers' groups. NGOs have a long record of being present at CGRFA meetings. The participation of ETC (formerly RAFI) and Practical Action (formerly ITDG) has been particularly notable. NGOs have been involved in advocating farmers' rights, and in general have been supportive of the CGRFA process. However, given that the discussions taking place in the CGRFA context are about agriculture, there is an on-going debate about whether farmers should in fact be the main stakeholder voice, supported by NGOs rather than NGOs seeking to speak on behalf of farmers. With this in mind, Practical Action is currently adopting a new model for engagement with farmers in the context of the Forum for Food Sovereignty, established in 2001. It is comprised of farmer organisations and fisher folks from different regions, supported by a number of specialists. The idea behind the Forum for Food Sovereignty is for the international platform to be driven by people and communities at grassroots level, supported by NGOs, rather than vice versa. From the NGO perspective, the Forum should be monitored and observed as a possible model for engagement with grassroots stakeholders in the future.

\subsection{Future arrangements for engagement with NGOs in multilateral institutions}

While formal arrangements for NGO engagement in intellectual property policy-making and normsetting activities in multilateral institutions are important, the nature of intergovernmental organisations is that Members retain decision-making powers and the role of NGOs will ultimately remain that of supporting and informing delegates in these processes. The most significant inputs of NGOs are likely to continue to be those of providing advice and technical expertise rather than in terms of direct participation through attending meetings organised by multilateral institutions and making interventions during these events. NGOs do not, and should not, rely on the panacea of enhanced formal participation in multilateral institutions in the future. Rather, their work is more effective at the informal level, providing advice and technical expertise in order to improve the flow of information and inform the policy-making and norm-setting process.

There is constant informal, off the record, dialogue between the various secretariats of multilateral institutions and NGOs but, since the policy-making and norm-setting process ultimately concerns Members, it is with latter rather than with secretariats that NGOs should continue to focus their efforts. To contribute to enhance their role further, NGOs can usefully enhance their engagement with government officials at the national level, particularly since it is at capital level that governments should be formulating policy.

The secretariats of multilateral institutions can assist with this process by ensuring transparency and the fast and efficient flow of adequate information on intellectual property policy-making and norm-setting activities to all stakeholders. In this respect, it should be noted that information is currently often available to international NGOs, with a presence in multilateral forums much faster than it is to Southern NGOs that operate at the national, regional and sub-national level. International NGOs, for instance, often receive hard copies of papers directly from delegates long 
before these are made available on official websites. More could be done by secretariats of multilateral institutions to ensure an inclusive approach that would encourage wider interest and understanding of their proceedings through greater transparency and more timely posting of documents. It should be noted, however, that constraints on transparency and timeliness might be driven by the concerns of Members rather than by secretariats of the various multilateral institutions concerned.

\section{Box 6}

\section{Summary of findings: arrangements for NGO engagement with multilateral institutions}

- For multilateral institutions engaged in intellectual property policy-making and normsetting activities, engagement with NGOs as a relatively recent phenomenon. These institutions are still evolving in terms of their relationships with NGOs.

- Multilateral institutions are, and should remain, member-driven institutions. NGOs should remain at the periphery of the policy-making and norm-setting process.

- There is a perception amongst the secretariats of multilateral institutions that Member governments should be the main point of contact for NGOs. However this perception is not uniformly accepted. The WIPO IGC and the FAO CGRFA, for instance, differ in this respect.

- While formal arrangements for NGO engagement in intellectual property policy-making and norm-setting activities in multilateral institutions are important, NGOs do not, and should not, rely on the panacea of enhanced formal participation in multilateral institutions in the future.

- The work of NGOs is more effective at the informal level, providing advice and technical expertise in order to improve the flow of information and inform the policy-making and norm-setting process.

- The secretariats of multilateral institutions can assist with this process by ensuring transparency and the fast and efficient flow of adequate information on intellectual property policy-making and norm-setting activities to all stakeholders.

\section{FINDINGS: PLANNING RESPONSES TO NEW AND EMERGING ISSUES}

NGOs have in the past mainly reacted to policy developments, a recent manifestation of this being NGO responses to intellectual property provisions in bilateral and regional trade agreements (FTAs). Recently, however, a more proactive form of NGO engagement with intellectual property issues has been apparent. In this respect, there is an increasing focus on alternative frameworks for promoting innovation, for example through a medical R\&D Treaty for neglected diseases, prize funds and the broader R\&D debate and A2K. Copyright is increasingly the focus of NGO work, as is technical assistance in developing countries and patent harmonisation. Another example is the WIPO Development Agenda, although to some extent this can also be seen to be defensive in that it is seen in some quarters as a counterweight to proposals for a Substantive Patent Law Treaty (SPLT).

Nevertheless, the prospect for a more proactive form of NGO engagement with intellectual property issues has its limits. The fact that NGOs have, in the past, been mainly reacting to policy developments is in part a problem of lack of resources in that NGOs and developing countries try to prioritise, to focus on what seems more important and to select issues on which they think that their input can be most significant.

Covering all intellectual property policy-making and norm-setting activities across multiple forums remains a huge task for NGOs. The dynamism of intellectual property issues in different forums 
and at multilateral, regional and bilateral levels makes it difficult for NGOs to cover all issue areas.

Relative to the resources available, NGOs have had a considerable impact, enriching the debate on intellectual property rights and development policy. However, NGOs must remain vigilant to ensure that they do not become donor driven, either explicitly or implicitly. Donor dependence can lead to pressures for NGOs to champion particular issues or to switch attention away from intellectual property rights and towards more tangible issues of immediate concern. Engaging with intellectual property issues requires long-term strategies on the part of NGOs. This must be underscored by long-term commitment on the part of donors. Over time the significance of contributions that NGOs have made to intellectual property policy-making and norm-setting activities in multilateral institutions will become more apparent, but this is not a short-term process.

\section{Box 7}

\section{Summary of findings: planning responses to new and emerging issues}

- In the past NGOs have mainly reacted to policy developments. Recently, however, a more proactive NGO engagement with intellectual property issues has been apparent.

- The prospect for a more proactive form of NGO engagement with intellectual property issues has its limits. Lack of resources have meant that NGOs and developing countries try to prioritise and focus on what seems more important, selecting issues where they think that their input can be most significant.

- Covering all intellectual property policy-making and norm-setting activities across multiple forums remains a challenge for NGOs. The dynamism of intellectual property issues in different forums and at multilateral, regional and bilateral levels makes it difficult for NGOs to cover all issue areas.

- Relative to the resources available, NGOs have had a considerable impact, enriching the debate on intellectual property rights and development policy. However, NGOs must remain vigilant to ensure that they do not become donor driven.

- Engaging with intellectual property policy-making and norm-setting activities requires long-term strategies on the part of NGOs. This must be underscored by long-term commitment on the part of donors.

- Over time the significance of contributions that NGOs have made to intellectual property policy-making and norm-setting activities in multilateral institutions will become more apparent, but this is not a short-term process. 


\section{RECOMMENDATIONS}

This report now concludes with six recommendations on NGO engagement with intellectual property policy-making and norm-setting activities in multilateral institutions. These recommendations, derived from the findings of the IP-NGO project outlined in previous sections of this report, are set out in box 8 below.

\section{Box 8}

\section{Recommendations}

1. International NGOs should focus more on providing advice and technical expertise to developing country governments at capital level to ensure that national government officials are aware of on-going discussions and developments in multilateral institutions.

2. International NGOs should improve coordination to avoid perceived duplication of effort.

3. International NGOs should assist groups in the South to build knowledge and capacity.

4. Multilateral institutions should make greater use of outreach activities such as regional consultations and public hearings.

5. Multilateral institutions should facilitate the positive contribution of NGOs by ensuring transparency and the fast and efficient flow of information.

6. Donors should make commitments to fund long-term strategies on the part of NGOs. 


\section{Box 9}

\section{APPENDIX}

\section{Interviews conducted for the IP-NGOs project}

The IP-NGOs research project has been informed by inputs from the individuals listed below, who were interviewed during fieldwork undertaken between November 2005 and June 2006. Any errors remain those of the author.

SWITZERLAND: Geneva/Zurich (including ad hoc observer status at $13^{\text {th }}$ Session of WIPO SCCR and $2^{\text {nd }}$ Session of WIPO PCDA)

Martin Watson (QUNO); Pedro Roffe (ICTSD); Julia Oliva (CIEL); James Love (CPTech); Sisule Musungu (South Centre); Ellen 't Hoen (MSF); Jennifer Brant (Oxfam International); François Meienberg (Berne Declaration); Cecilia Oh (WHO); Davinia Ovett (3D); Carin Smaller (IATP); Elizabeth Türk (UNCTAD); David Vivas (ICTSD); Anna Wang (Medicines for Malaria Venture); Rashid Kaukab (South Centre); Christoph Spennemann (UNCTAD); William New (IP Watch); Sangeeta Shashikant (TWN); Bernard Kuiten (WTO); Jayashree Watal (WTO); Adrian Otten (WTO); Charles Clift (WHO); Anthony Taubman (WIPO); Denis Croze (WIPO); Mathias Daka (Permanent Mission of Zambia); Alejandro Neyra (Permanent Mission of Peru); Ambassador Dr Manzoor Ahmad and Mujeeb Ahmed Khan (Permanent Mission of Pakistan); Maigari Buba (Permanent Mission of Nigeria); Ambassador Alberto L. Dumont (Permanent Mission of Argentina); Guilherme de Aguiar Patriota (Permanent Mission of Brazil); Eric Noehrenberg (IFPMA); Jose Victor V. Chan-Gonzaga (Philippines Mission to the WTO); a representative of the Permanent Mission of Kenya; Bernard Pécoul (Drug for Neglected Diseases Initiative)

\section{SOUTH AFRICA: Johannesberg/Pretoria/Cape Town/Stellenbosch}

Tenu Avafia (UNDP); Jonathan Berger (AIDS Law Project); Randall Williams (Department of Trade and Industry); Samu Dube and Louise Hilditch (ActionAid); Rachel Wynberg (Biowatch); Calvin Manduna (TRALAC); Angela Andrews (Legal Resources Centre)

BRAZIL: Sao Paulo/Curitiba (including ad hoc observer status at CBD COP 8)

Carlos Passarelli (Brazilian Ministry of Health); Jorge Beloqui (GIV); Maristela Basso (IDCID); David Hathaway (Interpreter, consultant, economist); Luis Eugenio Cifuentes (IMCA and CBCD, Colombia) and Alejandro Montero (CET-SUR and CBCD, Chile); Susan Finston (American Biolndustry Alliance, Washington D.C.); David Cooper and Marie Annick Moreau (CBD Secretariat, Canada); Representatives of Brazilian local peoples groups: Cemen (Cooperativa de mujeres estrativistas)/Estado de Pare, Ilha de Marajó; Edna Marajoara, Directora; Seringal Bon Futuro / Estado de Acre, Island on Rio Libertade; Lorival Montero (Comunidad local de Seringueros (rubber-tappers)) Estado de Acre - Edison Bastista (Local Communities of the Amazon); Michael F. Schmidlehner (Amazon Link)

INDIA: Delhi

Anand Grover (Lawyers Collective HIVIAIDS Unit); B K Kealya (National Working Group on Patent Laws); Amit Gupta (Delhi Science Forum); Vandana Shiva (Navdanya); Suman Sahai (Gene Campaign); Devinder Sharma (Forum for Biotechnology and Food Security); Biswajit Dhar (Centre for WTO Studies, Indian Institute of Foreign Trade)

\section{UNITED KINGDOM}

Geoff Tansey (consultant); Michael Bailey and Ruth Mayne (Oxfam GB); Ruth Okediji (University of Minnesota, USA); Patrick Mulvany (Practical Action/ITDG) 


\section{TELEPHONE INTERVIEWS}

In addition to face-to-face interviews, the telephone interviews were undertaken with the following individuals between December 2005 and June 2006:

Roger Chennells (SASI, Stellenbosch, South Africa); Andre de Souza (Pontifícia Universidade Católica do Rio de Janeiro, Brazil); Michel Lotrowska (MSF, Rio de Janeiro, Brazil); Chee Yoke Ling (TWN, Malaysia); Pat Mooney (ETC, Canada); Tewolde Berhan Gebre Egziabher (Environmental Protection Authority, Addis Abbaba, Ethiopia); Clive Stannard (FAO, Rome, Italy)

WRITTEN RESPONSES

Written responses were also received from the following individuals between February and May 2006:

Jean Marc von der Wied (AS-PTA, Rio de Janeiro, Brazil); Renata Reis (ABIA/REBRIP, Rio de Janeiro, Brazil); Carlos Correa (University of Buenos Aires, Argentina); Steven Price (Public Interest Intellectual Property Advisors, Washington, D.C., USA) 